\title{
SERVICES PROVIDED BY THE NATIONAL ARCHIVES IN PARIS (PIERREFFITE-SUR-SEINE) AND THE DEMANDS OF XXI CENTURY
}

\author{
PAULINA DĄBROSZ-DREWNOWSKA
}

University of Szczecin, Faculty of Management and Economics of Services, POLAND

e-mail: paulina.dabrosz-drewnowska@wzieu.pl

\begin{abstract}
RECEIVED
18 January 2018

ACCEPTED

2 September 2018

JEL

CLASSIFICATION

A12, M14

KEYWORDS

archive, National Archive, Paris, services

ABSTRACT

The aim of the article is the analysis of the services provided by the contemporary archival institution taking as an example the National Archives in Paris. This institution could be considered exemplary for archives in Poland. The article enumerate the main available archival services which are essentials for consultation and elaboration of the archival resources, quicker access to them, public availability and other facilities like the possibility of making specialized reprographics.
\end{abstract}

\section{Introduction}

The Archives are the institution which gather, store and share the archival resources. They are situated in the building equipped with technical standards, adapted for safe storing of the materials. The role of the archives as storing sources institution important for the history of every nation is essential for the society. The XXI century and the social transformations bring the changes in the functioning of the archives. Firstly, the public institutions become 
nowadays the service providers for the citizens as part of the informative society where the information is a product and the area of services is strongly developed.

The Archives stopped to serve only the scientists, qualified users who are adapted to work individually there (searching and reading the sources). Today, we are the witnesses of new role of the Archives. They become the service institution which provide services for strictly defined client. They require good management, professional approach and strategic planning (Jabłońska, 2014, p. 9). The Archives functions passes from the passive to active. Their basic functions as gathering, storing and elaborating the sources constitute the internal tasks. Sharing of the resources, the last of their functions become the essential service. Nowadays, the Archives get also other roles: assisting in the research, decrypting the sources, explaining and even understanding the archival materials, like also encouraging people to use new and unexplored area of knowledge. The process of democratization of Archives takes place which means that they become disponible for everyone without previous specialized preparation to work there, people's interests, age or profession. The profile of people using or interested in archives has changed through times. The contribution of the scientists decreased significantly in the last ten years. The "normal" citizens who search for the traces of their ancestors or the information from the family's past are dominants (Kwiatkowska, Jabłońska, 2017, p. 264). The definition of the archive user changes.

The internet, which is now the most important communication means plays the crucial role in this process. IT technics are the tools used for creating the information on large scale in the archival institution. Thanks to them, the work is more accessible and quicker. The development of the informative society simplifies the evolution of the services related to internet- transferring, processing and storing of the information. In Poland, this process is very slow. It's mostly due to the fact that archives are not sufficiently financed by the government (archives as part of public finance sector). They received too few funds for their maintenance and activity. In result, the building is not renovated, new standardized UE equipment is missing and in fact there is a difficulty in accomplishing their basic functions. The financial aspect constitute a major obstacle for efficient adaptation of polish archives to a place equipped with modern technics facilitating the scientific work which would significantly cut the time of many procedures related to reservation of the materials.

In other words, the polish archives are far from the standards and functioning offered in the archives in other European cities. The example of perfect organization and sharing of the materials and advanced exploiting of modern technics in providing archival services is the National Archives in Paris. They are adapting perfectly to the changing reality of XXI century. The article describes particularly one of three buildings of the Archives Nationales which is situated in Pierrffite-sur-Seine (59, rue Guynemer), in the suburbs of Paris.

\section{History and the role of the institution today}

The National Archives in Paris was created 12 September 1790 by National Constituent Assembly. The role of the institution was described in the rulings from 12 brumaire year II (2 November 1793) and 7 thermidor year II (25 July 1794). All the citizens had full access to them (Branda, Pinaud, Zacharie, 2008, p. 28). At that time, the formulated principle of the public archives made the institution public, open and freely accessible. With time, this principle started to function also in other countries. From the beginning of the existence of the Archives, the legislators were convinced of their importance. In 1800, Napoleon placed them in Hôtel de Soubise, located in the center of Paris, in the district Marais. Today, the building is the museum where the most precious documents are stored. In 1927, the Archives were moved to Hôtel de Rohan, the building in baroque style. In 1972, the part 
of the materials, (in particular the ones of ministries) were moved to Fontaineblau. As the volume of the resources became significant, in 1988, new building Caran (centre d'accueil et de recherche des Archives Nationales) was constructed near Hôtel de Rohan. After certain time, that building also became insufficient and because of the location in Fontainebleau, the access to Archives was limited. In 2004, with the support of the president of the French Republic, Jacques Chirac and the prime minister Lionel Jospin, the building in Pierrefitte-sur-Seine was chosen as the new seat of the Archives. It's well communicated with the city center. It's a place located near the underground terminus station of the line 13 (Saint-Denis-Université), very close to the University Saint- Denis. This very modern building is an archival center of Europe. The building is designed by the architect Massimiliano Fukas. It was opened in 11 February 2013 by the president François Hollande (Histoire..., 2018). We should underline the fact that the governmental authorities and presidents take a lot of care of the Archives which are principal institution for maintaining the national identity. The building in Pierreffite-sur-Seine (Figure 1) gathered all the documents which were dispersed earlier in many places. The project realized the national ambitions to create Grand Paris, promoting the public access and the cultural democratization (Pierreffite..., 2018). The building has $66000 \mathrm{~m}^{2}$ of usable area from which $5,400 \mathrm{~m}^{2}$ is for public use and $320 \mathrm{~km}$ is of storing areas. In the building, the sources are stored starting from the year $1790 .^{1}$

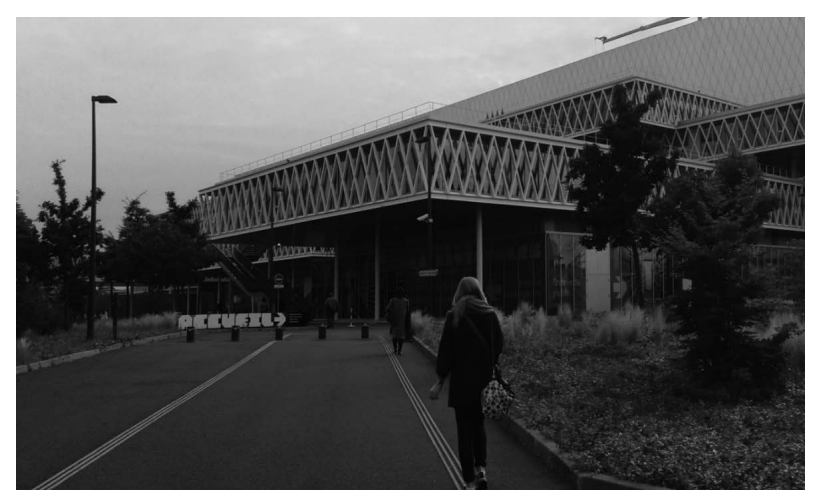

Figure 1. The main entrance to the National Archives in Pierreffite-sur-Seine Source: personal resource.

\section{The process of sources sharing}

The National Archives are open for everyone. We can meet there people who come for scientific purpose, the students as well as the passionate historians and those who search for their family roots. The first tool to use to start the research is the French internet website (http://www.archives-nationales.culture.gouv.fr/) translated into English and Spanish. We can find there all the basic information and plunge into 24,000 inventories in electronical version (search our catalogue, the online catalogue option). For more professional research, there are advanced

${ }^{1}$ In Rohan-Soubise, there are materials before the year 1790 (Ancien Régime) and the notarial materials. In Fontainebleau, the electronic and audiovisual materials are stored. 
browsers which facilitates and shorten its time. This part can be done from home and on the spot, users can plainly concentrate on the work with the source itself. New inventories are constantly registered in the electronical database. They are precise and they contain the descriptions of the respective sources. This is practical for the users outside France who can prepare for the source consultation before their arriving to the country. Inventories could be downloaded directly from the website. The user card is free after creating the account online. After the registration, the users can freely command the documents on their internet account. The user profile facilitates the research like saving found information (save search results option). This system doesn't function in any polish archive. It is comfortable and it permit to plan especially the distance work. However, the visit in the archives is inevitable because the system online doesn't contain all the information. The researchers can use des salle des inventaires where there are inventories in paper version and other tools like dictionaries or research papers helping to elaborate the sources. In the archives reading rooms, there are computer stands where the users can book the documents. In case of any difficulty related to reservation, they can always ask the employees for assistance. The daily limit of booked documents is 5 boxes. There is no limit for microfilms disponible in other reading room. They can be found in open drawers freely accessible. The materials can be booked any time during the day and the average time of waiting is 40 minutes. There is only one inconvenience that the employees of the reading rooms lack of specific archival knowledge in comparison to polish ones who are qualified historians. The employees in France are only able to indicate the inventories and assist in general research. The specialists work directly on conservation and storing of the sources. Then, the individual archival knowledge of the user needs to be in use together with the tools at his disposal. Fortunately, the computer tools are simple enough to permit the basic research without any previous historical training. Polish employees of the Archives are more competent and this is because polish institution lack of specialized tools like inventories and resources browsers in electronical version.

The fast and advanced process of digitalization of Archives is undoubtedly considered as one of the advantages of the institution. The new documents are digitalized in the National Archives and the database contain $1.9 \mathrm{mln}$ of sources disponible on-line (the audiovisual and electronic archives). In any place or time, the sources could be consulted. The programs used for the digitalization are much better than the polish ones and in result the consultation of the electronical source is more comfortable. In Poland, the digitalized sources, mainly from the Central Archives of Historical Records in Warsaw (AGAD) or the Archive of New Acts, are disponible on the website www.szukajwarachiwach.pl., which shares the resources online. All those facilities influence the growing number of people consulting the archival materials. It is clearly confirmed in the statistics shown below (Table 1).

Table 1. Attendance of reading rooms, Internet portal and virtual inventory room, research and waivers in the National Archives of France in 2017

\begin{tabular}{cccccc}
\hline Period & Working sessions & Registered readers & Communications & $\begin{array}{c}\text { Page views } \\
\text { for the website }\end{array}$ & $\begin{array}{c}\text { Unique visitors } \\
\text { to the virtual inventories }\end{array}$ \\
\hline 2017 & 38,823 & 16,256 & 141,224 & $12,666,661$ & 438,303 \\
2016 & 39,517 & 13,321 & 142,409 & $1,158,867$ & 508,971 \\
2015 & 40,475 & 15,098 & 140,764 & 10,087523 & 352,274 \\
\hline
\end{tabular}

Source: own study based on: Key figures (2018). 


\section{Using Conditions of the sources}

The vast area of the Archives in Pierreffitte-sur-Seine is appropriate for scientific work to make the user spend all day there. He can keep his personal stuff and clothes in the special boxes locked with the user card or a single code chosen by the user. The reading rooms are very spacious. The tables are big and the chairs are comfortable (Figures 3,5 ). The special trolleys for heavy document boxes are at disposal. The reading rooms can be accessed only with the user chip card.

In other part of the building, there are spaces for regeneration and meal, the bar, the machines with drinks and snacks and the terrace with stunning views and the sound of waterfall (Figure 4). Around the archives, there are swimming pools which give the impression of being on the island (Figure 2). It's the modern design solution of the building. There is also a special system of air conditioning which make the work agreeable even during hot days.

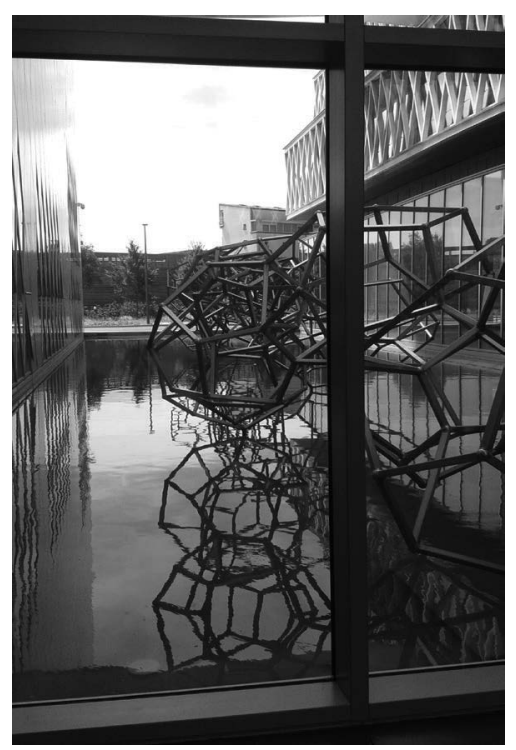

Figure 2. The view from inside of the The National Archives in Pierreffite-sur-Seine

Source: personal resource.

Figune 3. The reading room (the National Archives in Pierreffite-sur-Seine)

Source: personal resource.

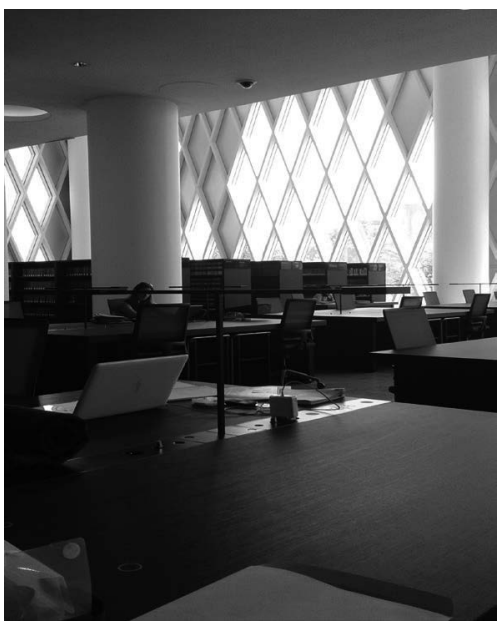




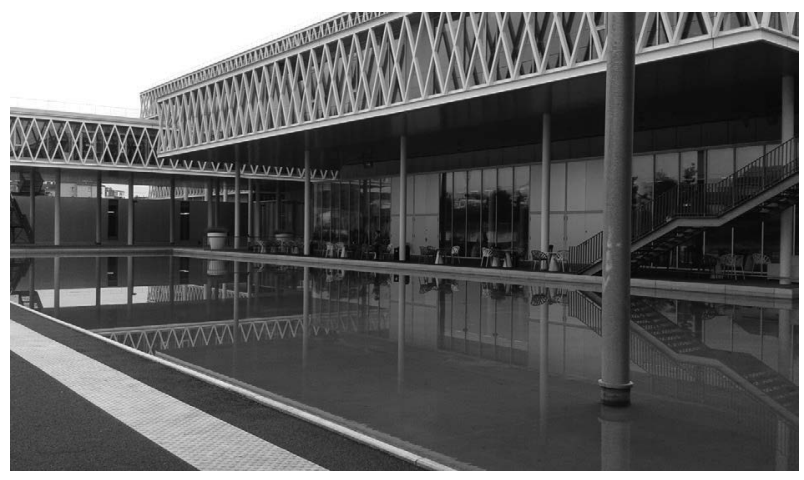

Figure 4. The vie on the terrace (the National Archives in Pierreffite-sur-Seine)

Source: personal resource.

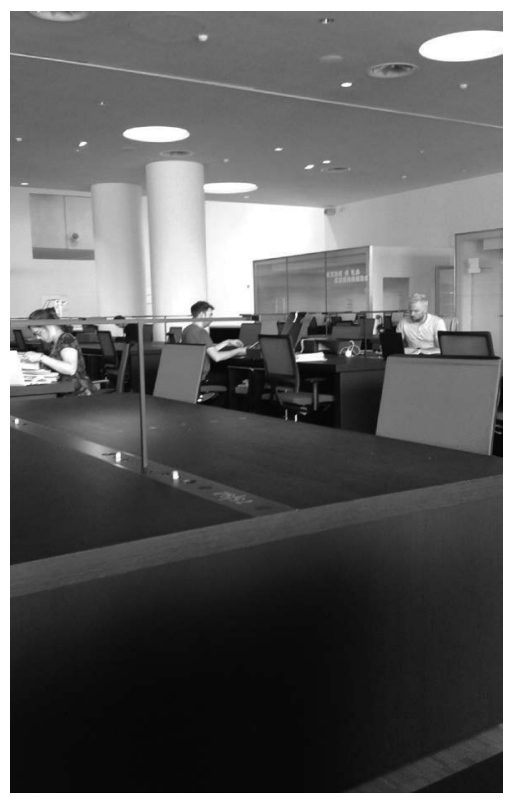

Figure 5. The reading room (the National Archives in Pierreffite-sur-Seine)

Source: personal resource.

\section{Reprographics services}

Another facility in the Archives is the possibility of making copies with the user's own digital camera without flesh. There are special tripods disponible for more professional photos. The consultation of certain private archival records requires permission of the reading room's manager. The more proficient document scans can be booked in the reprographics studio situated near the reading room. Xerocopies or scans in small quantity are made immediately 
or the same day or during the next few days if there are a lot of demands. The reprographics are done with the very good quality equipment and with color xero machines. This service is done quickly by the qualified stuff. The prices of xerocopies and scans are competitive than in any copy shops offering even better quality services. ${ }^{2}$

\section{Other services}

Apart from sources sharing and reprographics, the Archives propose also other services. There is a shop selling books and archival souvenirs like pens, bags etc. Technical standards permit to organize in the Archives various expositions and conferences. The institution is part of the west European Archives politics which support and promote their own cultural, educational and popular activities. In XIX century, the pioneer pedagogical department was created in the National Archives and it was responsible for preserving the cultural patrimony (Kowalczyk, 2013, p. 107). The archives provide a large offer for pupils or students. The statistics say that 9,634 pupils visited the two sites of the Archives in 2017 (Paris et Pieriffitte-sur-Seine), 474 primary and secondary school teachers took part in basic or advanced training courses. 1,014 visitors participated in social outreach programs. After all, National Archives educational service proposes over 50 workshops and visits for schools and universities to make the young people discover the history by studying archival records. The offered activities are available on both sites and their subjects vary as per site: the activities at the Pierrefitte-sur-Seine site are related to public archives dating from 1790 and collections from private sources. The workshops at the Paris site concern the resources dating from the Ancient Régime time. All activities are organized with the same schema. The pupils or students visiting the National Archives in Paris or Pierrefitte-sur-Seine study first the documents that are part of the national heritage and then learn how to elaborate them (collecting, conserving, providing access to, and making optimal use of the documents). A workshop or exhibition is to transfer and revise the knowledge on a chosen subject. At the end of the workshop, a participant is asked to produce a work or give an oral summary of what he learned. During each workshop there is enough time for discovering original documents in the showcases or the temporary exhibition areas.

The National Archive prepared also a special offer for teachers - educational supports which help to work on core archival skills. It gives them a hand with teaching projects in various disciplines like history, literature, science, modern languages, and art. The activities are adapted to the level and progress of the school classes according to the national curriculum. Some of them are oriented for artistic and cultural education and practical interdisciplinary teaching. They are a way to include information and communication technologies in teaching activities. Participating in specific workshops constitute a major part in obtaining the IT and internet school certificate (brevet informatique et internet).

Summing up, the National Archives services take active part in knowledge, culture and education development in France.

\section{Conclusions}

The statistics present a considerable number of people attending the National Archives in Paris. It confirms the efficiency of the applied solutions in the process of democratization of archival services and development

\footnotetext{
${ }^{2}$ Color photocopie costs 30 euro for A4 page size (illegible source is scanned in first place and then printed for 0.30 euro; in case of the distance demands, there is an additional cost of 7 euro and the for the commands lower than 20 pages it's 60 euro for one A4 page size. www.archivesnationales.culture.gouv.fr/documents/10157/11409/d\%C3\%A9cision+tarifaire+tarif+reproduction-18juin-web. pdf/57e5b767-8f88-4272-8d45-8e89f2c9e987. For AGAD the printed copy costs 2 zl for A4 page size: Regulamin..., 2018.
} 
of the informative society. The public access to the institution is facilitated by the IT system. The resources can be consulted and booked easily and quickly without limit where the assistance of the qualified employees with archival education is not needed. Those work directly on conservation and storing of the sources. The archival work is then highly advanced and simplified particularly for professional researchers. Apart from basic sharing sources service, the Archives give the possibility of quick and professional reprographics and assure the work comfort of the user to consult the records. In contrast to the Archives in Poland, the enormous funds have been transferred to build, equip and maintain National Archives in France. For polish ones like the Central Archives of Historical Records in Warsaw (AGAD), the governmental funds for maintenance, functioning and development are missing. The building of the Archives is situated in the center of Warsaw on the main tourist route. It is supposed to be an exemplary archival institution in Poland but it requires urgent repair and renovation of the façade.

To conclude, the National Archives in Paris becomes the exemplary institution proposing a wide range of services which puts one step ahead his modern user, preserving at the same time its traditional character.

\section{References}

Branda, P., Pinaud, P.F., Zacharie, C. (2008). Quand Napoléon inventait la France. Dictionnaire des institutions politiques, administratives et de cour du Consulat et d'Empire. Paris: Tallandier.

Histoire de l'institution (2018). Archives Nationales. Retrieved from: www.archives-nationales.culture.gouv.fr/web/guest/histoirede-I-institution.

Jabłońska, M. (2016). Nowe wyzwania archiwów. Komunikacja społeczna i public relations. Toruń: Wydawnictwo Naukowe Uniwersytetu Mikołaja Kopernika.

Key figures (2018). Archives Nationales. Retrieved from: www.archives-nationales.culture.gouv.fr/en/web/guest/chiffres-cles.

Kowalczyk, U. (2013). „Otworzyć świat archiwów na inne formy ekspresji kulturalnej”. Działalność kulturalna i edukacyjna Archiwum Narodowego Francji. In: Archeion. Tom CXIV (pp. 107-114). Warszawa: Naczelna Dyrekcja Archiwów Państwowych.

Kwiatkowska, W., Jabłońska, M. (2017). Nowe wyzwania archiwów. Komunikacja społeczna i public relations. Recenzja. Folia Toruniensia, 17, 264.

Pierrefitte sur Seine (2018). Archives Nationales. Retrieved from: www.archives-nationales.culture.gouv.fr/documents/10157/11361/ batiment-an-pierrefitte.pdf/38412b65-454c-4454-b541-272772ace035.

Regulamin świadczenia usług archiwalnych. Archiwum Głównego Akt Dawnych (2018). Retrieved from: http://agad.gov.pl/wp-content/ uploads/2016/10/REGULAMIN-\%C5\%9AWIADCZENIA-US\%C5\%81UG-ARCHIWALNYCH.pdf.

The Central Archives of Historical Records in Warsaw (2018). Retrieved from: http://agad.gov.pl/.

The National Archives of France (2018). Retrieved from: www.archives-nationales.culture.gouv.fr/.

www.archivesnationales.culture.gouv.fr/documents/10157/11409/d\%C3\%A9cision+tarifaire+tarif+reproduction-18juin-web. pdf/57e5b767-8f88-4272-8d45-8e89f2c9e987.

Cite this anticle aS: Dabrosz-Drewnowska, P. (2018). Services provided by the National Archives in Paris (Pierreffite-sur-Seine) and the demands of XXI century. European Journal of Service Management, 3 (27/2), 115-122. DOI: 10.18276/ejsm.2018.27/2-14. 